\title{
ECONOMICS
}

\section{ON BRITAIN'S RETURN TO THE GOLD STANDARD: WAS THERE A 'PIGOU-MCKENNA SCHOOL'?}

by

Rogério Arthmar

Department of Economics, Universidade Federal do Espírito Santo, Vitória, Brazil

and

Michael McLure

Business School

University of Western Australia 


\title{
ON BRITAIN'S RETURN TO THE GOLD STANDARD: WAS THERE A 'PIGOU-MCKENNA SCHOOL'?
}

\author{
Rogério Arthmar and Michael McLure*
}

DISCUSSION PAPER 15.18

\begin{abstract}
On 17 March 1925, Britain's Chancellor of the Exchequer, Winston Churchill, held what is now regarded as a famous dinner with Sir Reginald McKenna, John Maynard Keynes, Sir John Bradbury and Sir Otto Niemeyer to discuss the merits, or otherwise, of Britain returning to the gold standard. Following that dinner, it has become popular to refer to the 'KeynesMcKenna school', with those two men being characterised as the 'antagonists' to the proposal for Britain to return to gold. However, in light of A. C. Pigou's reading of McKenna's evidence to the 1924-25 Chamberlain-Bradbury Committee, and Pigou's September 1924 draft of that Committee's report, it is evident that Pigou's views on the subject largely aligned with those of McKenna. As a result, it is suggested in this paper that historical reference to the 'PigouMcKenna school' as a school of thought that was supportive of Britain returning to the gold standard in principle, but not supportive of doing so prematurely, is a meaningful notion - and perhaps more meaningful than reference to the 'KeynesMcKenna school', which incorrectly implies that McKenna was opposed to Britain returning to the gold standard.
\end{abstract}

\section{Draft as at 24 June 2015}

\footnotetext{
* Rogério Arthmar, Department of Economics, Universidade Federal do Espírito Santo, Vitória, Brazil; Visiting Fellow, Economics Program, University of Western Australia, Business School. E-mail: rogerio.arthmar@ufes.br; and Michael McLure, Economics Program, University of Western Australia, Business School. E-mail: michael.mclure@uwa.edu.au. This paper draws on a draft paper that McLure presented at the Pigou Mini-Conference, 29 November 2013, Robinson College, Cambridge. We would like to thank the other participants at the Mini-conference- Nahid Aslanbeigui, Michael Ambrosi, David Collard and Mark Hayes - for their discussion and Simon Frost, the Deputy Librarian at the Marshall Library, Cambridge, for being so helpful and for facilitating our access to the Pigou papers. We would also like to thank Gregory Moore for providing comments on a near final draft of the present paper.
} 


\section{Introduction}

In his volume of reminiscences entitled Prejudice and Judgement (1948), Sir P. J. Grigg carefully chronicled the discussion at Winston Churchill's dinner on 17 March 1925 with Sir Reginald McKenna, John Maynard Keynes, Sir John Bradbury and Sir Otto Niemeyer. At the time, Churchill was Chancellor of the Exchequer, Grigg was his private secretary and the purpose of the dinner was to discuss the proposal for Britain to return to the gold standard. Following publication of Grigg's beautifully written account of that event, the literature dealing with Britain's return to the gold standard has tended to refer the event as Churchill's 'famous dinner party'.

This dinner party is famous for three reasons. First, its timing suggests that it was important to the decision making process, with records of public officials noting that Churchill reached a decision on the matter by either 19 or 20 March (Moggridge, 1969, p. 56) and Churchill announcing, in his budget speech of 28 April 1925, that Britain would be returning to the gold standard. Second, the meeting is presented as something of a polemic, with Keynes and McKenna paired up as the 'antagonists' to a return to gold, and Bradbury and Niemeyer paired up as the 'proponents' of that return (Grigg 1948, 182). The polemic character was subsequently underlined by Donald Moggridge who coined the phrase the 'Keynes-McKenna school' (Moggridge 1969, p. 61; 1972, p. 85). Moggridge’s choice of phrase was no doubt, in part, inspired by Bradbury’s memo, of 5 February 1925 to Niemeyer, in which he characterises the author of a Treasury memo on 'Mr. Churchill's exercise' as appearing to "have his spiritual home in the Keynes-McKenna sanctuary" (Moggridge 1969, p. 45). Third, after agreeing with Keynes that the discrepancy between British and US price levels implied by the gold standard was $10 \%$, and not $2.5 \%$ as implied by the actual exchange rate (Grigg 1948, 182), McKenna then says something like: "There is no escape; you have to go back; but it will be hell” (Grigg 1948, p. 184). In the words of Lord Skidelsky, "in the end McKenna, a former Chancellor, gave way... Keynes stood firm.” (1992).

Of course, the literature on the return to gold is extensive and much wider than just Churchill's much commented upon dinner. Among other things, considerable importance is also given to the activities of the "Committee on the Currency and Bank of England Note Issues”. This will, henceforth, be referred to as either 'the Chamberlain-Bradbury Committee' - after Sir Joseph Austen Chamberlain, its first chairman, and John Bradbury, who replaced him in that post when Chamberlain assumed as Foreign Secretary on 6 November 1924 - or 'the Committee'. The Committee, appointed by a Treasury minute of 10 June 1924, reported to Churchill on 5 February 1925 and advised him in unequivocal terms to make a rapid and decisive return to gold. Significantly, the two protagonists characterised by Grigg as favouring an immediate resumption of the gold standard at Churchill's famous dinner, also served on the Chamberlain-Bradbury Committee.

For the purpose of this study, however, the first point to emphasise is that A. C. Pigou was also a member of the Chamberlain-Bradbury Committee. The final report of that Committee was preceded by four draft reports, the second of which was prepared by Pigou and completed in early September 1924. Perhaps the key feature of Pigou's draft of the Report is that, instead of recommending a rapid return to the gold standard, it highlights that the matter will not become urgent for more than a year and suggests that a wait and see stance be adopted. Furthermore, the Committee interviewed McKenna on 10 July 1924; and, although Pigou was absent from the deliberations on that day, his personal copy of that record of interview is extant and it includes vertical lines drawn, in pencil, down the margin next to 
transcribed sentences. ${ }^{1}$ Pigou was clearly very interested in what McKenna had to say on Britain's return to the gold standard and he highlighted much of the testimony as a part of his preparations to write the September 1924 draft of the Committee's report. ${ }^{2}$

The general purpose of this paper is two twofold. First, to establish the character of Pigou's reading of McKenna's testimony. Second, to consider the content of Pigou's draft of the Committee's report, and reflect on the relationship between McKenna's testimony and Pigou's report to consider whether it is legitimate to talk of a 'Pigou-McKenna school' on Britain's return to the gold standard. In pursuit of this two fold purpose, the paper is structured in six sections. Section 2 briefly provides the historical context of the study, starting with the creation of the currency notes, followed by Britain's abandonment of the gold standard and ending with Pigou's appointment to the Chamberlin-Bradbury Committee. Section 3 provides an overview of McKenna's ideas on currency, credit and gold, which is followed by a narrative account of Pigou's reading of McKenna's testimony before the Committee. Section 4 considers Pigou's memorandum for the 1920 International Financial Conference in Brussels 1920 and the September 1924 draft of the Chamberlain-Bradbury Committee's report and their relationship to McKenna's testimony to that committee. Using the evidence presented, the case for the 'Pigou-McKenna school', as a school of thought that was supportive of Britain returning to the gold standard in principle but not supportive of doing so prematurely, is presented paper concludes, in Section 5. The paper concludes, in Section 6, that reference to the 'Pigou-McKenna school' is an appropriate way of characterising a significant missed opportunity in British monetary policy.

\section{Currency Notes and the Lead-up to the Chamberlain-Bradbury Committee}

With the formal declaration of war between Austria and Serbia on 28 July 1914, panic reached the British shores and banks started to call in their loans to the discount market and the stockbrokers. On Friday 31 July, the London Stock Exchange was shut down and the demand for rediscount at the Bank of England rose rapidly and forced the Bank of England to raise its rate from 3 to 8 percent - and to 10 percent the very next day, on Saturday 1 August. After emergency deliberations by authorities over the weekend, a royal proclamation was issued postponing payments on bills of exchange by a month - with the moratorium later renewed until 4 November - and the bank holiday on Monday 3 August was extended to the following Thursday. During this interval, a series of meetings involving authorities, bankers, merchants, industrialists and stockbrokers were carried out at the Treasury. On 6 August, among other measures to ensure an adequate provision of liquidity, and after a suggestion by the Clearing Banker's Association, the Currency and Bank Notes Act was rushed through Parliament in a single day to authorise the Treasury to issue currency notes of one and ten shillings in amounts the institution saw appropriate. Those notes were to be distributed through the Bank of England to financial institutions at the bank rate, which was reduced to 6

\footnotetext{
${ }^{1}$ There is little doubt that these lines were drawn by Pigou himself, not only because they are the transcripts Pigou's personal copy, but also because it is a practice that he adopted, although far less extensively, when reading transcripts of other interviews with the same Committee. Furthermore, the pencil lines match the one occasion when a few inconsequential words were written in pencil on a transcript in Pigou's unmistakable scrawl.

2 Pigou also drew vertical lines in the margins of transcripts of the Committee's interviews with others, but Pigou paid closest attention to what McKenna had said as his annotations on the transcript of the McKenna interview are much more extensive for McKenna than any other interviewee.
} 
per cent on that same day and to 5 per cent two days later (Peters, 1993; Seabourne, 1986; Morgan, 1952, pp. 3-32).

Despite the 1914 liquidity crisis, specie payments were formally maintained. For much of the war period, though, the risks associated with shipping were so great that insurance of gold being exported from Britain could not be obtained (Moggridge, 1969, p.11), so an outflow of gold would not be triggered by the exchange rate falling below the traditional gold export point. As the end of the Great War approached, the British Government started to give consideration to currency and exchange issues in the early post war period of reconstruction. In January 1918, Lord Cunliffe, the Governor of the Bank of England, was appointed to chair the "Committee on Currency and Foreign Exchanges after the War" (or the 'Cunliffe Committee', as it became known). Pigou was a member of this Committee, ${ }^{3}$ which was instrumental in setting the future agenda for monetary matters and in shaping the financial framework that the Chamberlain- Bradbury Committee confronted in 1924 and 1925.

In regard to the agenda for currency reform, the first interim report of the Cunliffe Committee (Currency and Foreign Exchanges, 1918) noted that witnesses appearing before the committee were at one concerning the restoration of the gold standard at pre-war parity; and recommended that this step should be taken as soon as permitted by fiscal constraint (cessation of Government borrowings) and monetary conditions (suitable machinery to allow the Bank of England discount rate to check a drain of gold overseas; and limitation of fiduciary issue). In regard to reaching that end, two conditions were noted in that report. The first one, which became operative before the Chamberlain-Bradbury Committee met, was the recommendation that the issue of fiduciary notes should become subject to law once again; with the final report of the Cunliffe Committee noting that effect should now be given to the recommendation of the interim report that the actual maximum fiduciary circulation in any one year become the legal maximum for the following year. The second condition was the termination, at the earliest possible moment, of the exchange of deposits of Bank of England notes for currency notes without affecting the reserves of the Banking Department.

A year after the Cunliffe Committee had reported, the US ceased its support for the sterling in 1919 (Eichengreen, 1992, p. 100-107) and in the following year, with the value of the pound declining, the British government introduced the Gold and Silver Export Control Act (1920) to virtually prohibit the export of gold for five years. This prevented Britain's gold reserves from being drained in the event of the exchange rate falling below the gold point. In effect, this meant that the transitional arrangements established in the post Cunliffe period could continue until 31 December 1925 (Sayers, 1976, v. 3, p. 55-56). On 21 May 1924, Sir Otto Niemeyer, in his capacity as the Comptroller of Finance at the Treasury, wrote to Pigou stating that "The Chancellor is appointing a small Committee to advise him privately whether the time has come to amalgamate the currency and the Bank of England notes issues" and indicating that "the Chancellor would be very grateful if you would consent to serve on the Committee” (Niemeyer in G1/433). Pigou then joined Chamberlain, Bradbury, Niemeyer, and Gaspard Farrer (Director of Bearings, Merchant Bankers) on that Committee, with Mr N. E. Young, from the Treasury, serving as Secretary to the Committee.

The Committee convened seven meetings to hear testimony from twelve invited witnesses, as well as other meetings without witnesses. Pigou's absence in July and August meant that he was only present when the Committee interviewed Montagu Norman, the

\footnotetext{
3 The views of Pigou around the time of his contribution to the Cunliffe Committee are discussed by Aslanbeigui and Oakes (2013).
} 
Governor of the Bank of England; and Charles Addis, a former Governor of the Bank of England. He had to rely on the transcripts of interview to read the testimony of McKenna; as well as that of other interviewees, such as those associated with the Treasury ${ }^{4}$, the financial sector, ${ }^{5}$ industry in general ${ }^{6}$ and academia. ${ }^{7}$ However, Pigou was diligent in reviewing the transcripts of interview from the meetings of the Committee that he missed and the testimony of McKenna was, judging from the number of lines he inserted to highlight text, of particular interest to him.

The final report of Chamberlain-Bradbury Committee, submitted to Churchill on 5 February 1925, advised the Chancellor to make a rapid and decisive return to gold. In the introduction to his Gold Standard Bill (1925), Churchill explicitly referred to the Committee's final report (Currency and Bank Notes, 1925) as crucial: "It contains a reasoned marshalling of the arguments which have convinced His Majesty's Government, and it sets forth a series of recommendations, in which my right hon. Friend [Chamberlain], though he ceased to be Chairman on becoming Foreign Secretary, has formally concurred, and which His Majesty's Government are intending to follow in every respect” (Financial Statement, 1925, cc. 52-58).

\section{McKenna and Pigou's Reading of McKenna's Testimony}

McKenna (1863-1943), a Liberal MP from 1895 to 1918, was appointed as the Financial Secretary of the Treasury in 1905 when H. H. Asquith was the Chancellor of the Exchequer. Shortly after that he was appointed to Cabinet rank, holding a range of ministerial level appoints until, in 1915, he succeeded Lloyd George as the Chancellor of the Exchequer in Asquith's government. He remained in that office until late 1916 when Asquith was replaced as Prime Minister because the Liberal Party was in a state of political crisis due to its war policy. McKenna became a director of the Midland Bank in 1917 and held the post of chairman of that Bank from 1919. His invitation to give evidence to the ChamberlainBradbury Committee was, no doubt, made in recognition of McKenna's capacity as a former Chancellor of the Exchequer, when he was at 'the height of his powers' (Cregier 2014), and, as the current chairman of the Midland Bank. ${ }^{8}$

\footnotetext{
${ }^{4}$ The two other interviewees with links to the Treasury were Sir R. S. Horne, Chancellor of the Exchequer (1921-22) and Sir George Paish, former advisor to the Chancellor of the Exchequer.

${ }^{5}$ The interviewees from the financial sector were Mr L. Currie, partner of Glyn, Mills Currie \& Co, Sir Felix Schuster, director of the National Provincial Bank, Sir W.H.N Goschen, partner of Goshens and Cunliffe, Dr Walter Leaf, chairman of Westminster Bank and Mr F. C. Goodenough, chairman of Barclay’s Bank.

${ }^{6}$ The interviewees representing the Federation of British Industries were Messrs Chisholm and Glenday.

7 The two academic economists interviewed were John M. Keynes, fellow of King's College Cambridge and Edwin Cannan, professor of political economy at the University of London.

${ }^{8}$ McKenna's annual addresses to the Bank’s stockholders from 1920 to 1928 were compiled in the volume PostWar Banking Policy (1928). Keynes, who had worked under McKenna as a public servant, observed that, through McKenna's annual bank addresses, the former Chancellor of the Exchequer helped make the entrenched orthodoxy of the twenties disappear like 'the old London fogs' (Keynes, 1972, p. 58).
} 


\subsection{McKenna's First Target: a Monetary Regime to Deliver Stable Exchange Rates}

Unlike Keynes, ${ }^{9}$ McKenna was not opposed to Britain returning to the gold standard; rather, he opposed instead a premature resumption of the old sterling-dollar parity. When asked by members of the Chamberlain-Bradbury Committee if 'the fact' of a stable exchange rate with the US dollar, which had already returned to the gold standard, ${ }^{10}$ was a reason for Britain going back to the gold standard as soon as possible, he replied by saying 'no it is not'; he then offered three reasons why Britain may want to return to gold. The first one was that public confidence in a currency, be that confidence unfounded or founded, was a pertinent consideration when setting the monetary regime. In his understanding, gold still commanded widespread public respect. The second reason was that the monetary regime established for Britain should be set with regard to real economic benefits for the British Empire, and not just for Britain itself. In that regard, he reminded the Committee that empire countries, like Australia, were gold producing countries. The third reason, which is also related to public confidence in a currency, is that simple monetary arrangements allow the public to have a greater understanding of the monetary system. In that regard, the public understood the gold standard better than monetary policy managed through credit arrangements.

But if these three factors in favour of the return to gold are to be decisive, stability must first be attained. That is, McKenna did not see a return to gold as creating financial stability, but once that situation has been attained, then the gold standard can assist in the maintenance of stability. The first order point in that regard is McKenna's contention that it is not the level of the exchange rate regime that is important, but the gains from international trade associated with the exchange rate regime that is important. If the exchange is stable relative to commodities - as suggested by the relative version of purchasing power parity and if the exchange is stable relative to gold, then trade is in a position to flourish following the introduction of a gold standard. To return to the gold standard at pre-war parity from an exchange rate that is moderately below that parity, price levels in Britain must rise slower (or fall faster) than price levels in her trading partners such as the United States. Once monetary policy aimed at reducing relative price levels causes the exchange rate to appreciate and return the currency to the pre-war gold standard exchange rate, the gold standard can be reintroduced and monetary policy aimed at influencing domestic price levels relative to the US can continue to maintain the exchange rate at the gold parity rate.

To defend the view that trade flourishes with exchange and price stability, such as that associated with the gold standard, McKenna emphasised that Britain's trade was not advantaged by any particular level of the exchange rate.

"There is no question in my mind of there being any advantage of trade of the Exchange being at one level more than another level ... There may be advantage in getting down to a level, there may be disadvantage in getting down to a level; there may have been advantage in getting up to another level, there may have been a disadvantage in getting up to another level. But when you are there, stay there so far as trade is concerned."

(McKenna in: ACP 4 F25, p. 21).

When viewed in the context of a return to the gold standard, McKenna's reference to 'when you are there' means when the sterling has successfully returned to the pre-war gold parity exchange rate where one pound exchanges for 4.86 US dollars. But a stable exchange rate

\footnotetext{
${ }^{9}$ Keynes’s views on monetary policy at this time are discussed succinctly in Meltzer (1983).

${ }^{10}$ While the US did not 'formally' suspend suspended specie payments on entering World War I, within a matter of months President Wilson had issued a proclamation requiring all parties proposing to export gold from the US to apply to the Secretary of the Treasury and the Federal Reserve Board for permission to do so, with all such applications being denied from September 1917 to June 1919 (Crabbe 1989, p 426).
} 
with stable prices is only the first of two necessary conditions for a return to gold. The second concerns the stability of the gold price itself. Because of the interdependence between the exchange rate and the gold price, especially in a world where some nation's exchange rates are pegged to the gold standard and some are not: "I would not be at 4.86 without that [stability]. I do not want to fluctuate. If gold is going to fluctuate I do not want to fluctuate with gold: I want stability” (McKenna in: ACP 4 F25, p. 22).

McKenna's views on these relationships were unequivocal. For example, he rejected any suggestion that the present exchange rate was a result of sentiment. It was, in his view, completely determined by the price level in Britain relative to the price level of other nations. ${ }^{11}$ Indeed, when divergence between movement in relative sterling-US dollar exchange rate and movement in the relative British-US price level was evident from estimates of price levels, McKenna suggested that that would be probably due to error in deriving price estimates and not the result of sentiment.

All this led McKenna to advocate for a 'wait and see' approach to avoid a premature return to gold. In 1924, the pound could buy less than 4.86 US dollars, but as price levels in Britain were growing slower than in the US he expected the pound to appreciate to parity before the prohibition on the export of gold terminated at the end on 1925. "In the language of a great statesman, 'wait and see'. American prices will probably be up to that level before the $1^{\text {st }}$ January 1926 . We shall automatically be on the gold basis when we open our mints." (McKenna in: ACP 4 F25, p. 18). Sir John Bradbury correctly characterised McKenna's position in the following terms:

"Now am I correct in saying that the advice you would be disposed to give would be to do nothing at all until such time as the pressure of events brings Sterling to par, and then to have an international monetary conference with a view to settling the general terms, as between nations, for the ultimate resumption of the gold standard? Is that a correct summary?” ${ }^{12}$

(Bradbury in: ACP 4 F25, p. 24).

\subsection{McKenna's Second Target: A Stable Gold Price to Support a Stable Exchange Rate}

To maintain a stable gold price, McKenna argued that countries on the gold standard were, in effect, obliged to enter gold markets to purchase gold when there is downward pressure on gold prices even when those purchases are not required as reserves for strictly monetary purposes. At the time of the Committee's enquiry, the US was actively buying the metal as a means of keeping the price of gold steady.

"Now if gold were depressed in value the United States being on the gold standard, that is today, having their Mints open and obliged to coin gold on demand into dollars, if the gold were allowed to fall in value the dollar would also fall in value and immediately prices would rise in the United States and the United States would get into a state of real bad inflation.”

(McKenna in: ACP 4 F25, pp. 9-10).

As a gold standard country, McKenna observes that the US has undertaken two actions to prevent the emergence of high rates of inflation following a fall in the price of gold. First, it has become a major buyer in international gold markets. In that regard, he estimated the value of world consumption of gold to be about 70 million pounds sterling, 60

\footnotetext{
11 "Chamberlain: You think it is entirely dependent upon the price level? McKenna [in reply]: Price level entirely.” (ACP 4 F25, p. 19).

${ }^{12}$ McKenna’s reply confirmed that Bradbury’s characterisation had correctly summarised his view.
} 
million of which was purchased by, or deposited in, the US to support the price of gold; with the remaining 10 million pounds of gold purchased by 'genuine buyers' (McKenna in: ACP 4 F25, p. 9). Secondly, McKenna points out that the US sterilises the impact of excess gold purchases, undertaken for the purpose of maintaining the gold price, on overall credit creating capacity. It did so through the Federal Reserve, which selling securities. ${ }^{13}$

The moment that Britain returns to the gold standard, it would have to join with the US in meeting a share of the cost of gold price maintenance activities. It would have no alternative but to 'buy gold'. But if Britain decided it could afford to contribute to the cost of gold price maintenance and returning to the gold stand is the intention, then McKenna regarded the question of whether Britain should, or should not, sterilise all or some of its gold surplus as very important. As McKenna saw it, Britain's capacity to sell securities to sterilise associated credit growth following the purchase of gold was diminished by its weak fiscal position and large national debts. In view of this, his preferred solution would be to not sterilise all of the gold inflow from gold price maintenance activities, leaving some of it as a basis for providing new credit opportunities because a modest degree of inflation is conducive to trade and economic growth. ${ }^{14}$ Consequently, once Britain returns to the gold standard and adds to its gold surplus to maintain the price of gold, the extent to which that increase in the gold surplus needs to be sterilised is consistent with maintaining relatively modest inflation rate in Britain, provided it does not exceed the inflation rate in the US (and other countries that also return to the gold standard). A rapid re-establishment of the old parity before the change in price levels in the US relative to Britain had brought the exchange rate back to its pre-war level would, in McKenna's view, be folly.

When quizzed by Austen Chamberlain on what would happen if the Chancellor of the Exchequer were simply make an announcement on the matter, without waiting to the exchange appreciates above the gold point, McKenna replied: "I should liken him to King Canute who told the tide to recede. ... " (McKenna in: ACP 4 F25, p. 18).

\begin{abstract}
"Nothing that he [the Chancellor of the Exchequer] could do in the way of restricting credit here and forcing down prices in this country would get him to the gold standard. He would cause infinite trouble, cause unlimited unemployment, immense losses and ruin, but he could not balance his Budget while he was doing it, and he would have to begin to borrow. Before he got our price level down $10 \%$ he would be borrowing again because his revenue would not be coming in. He would be having to inflate before he got there. The Budgetary difficulty will always beat them in forcing down prices.”
\end{abstract}

(McKenna in: ACP 4 F25, p. 18-19).

\footnotetext{
13 “In order to prevent ... [that 'real bad inflation'] happening the United States buy all this gold and do not allow it to become the basis of new credit. They achieve that object in this way. As fast as gold is poured into the Federal Reserve Bank creating thereby an additional account of Bank cash in the hands of the Banks who have brought the gold and sent it into the Federal Reserve Bank, the Federal Reserve immediately reduces the amount of Bank cash by selling securities or Bills. I call a Bill a security of course. Just as I said the Bank of England could reduce credit by selling securities, so the Federal Reserve Bank reduces cash by as fast as cash would have been increased by the sale of gold.” (McKenna in: ACP 4 F25, p. 10).

14 “...the effect would be to introduce a long slow period of rising or inflated prices due to varying value [stocks] of gold and, in view of the immense national debts, I think the easiest way to get rid of an excessive burden which the taxpayer cannot bear is by a slow process of inflation. You have to distinguish this from what is ordinarily termed inflation because I do not mean the inflation of 1919 nor the ordinary credit inflation which is done voluntarily. I do not mean that. I mean precisely the same inflation as this country had from the year 1901 to the year 1914. Prices were during that period steadily tending upward owing to the oversupply of gold. ... I think it would be good for our trade because it would mean a period of rising prices, rising prices restricted by the quantity of gold and, therefore, not due to an unrestricted issue of currency by a defaulting Government.” (McKenna in: ACP 4 F25, p. 12).
} 


\section{Pigou's Draft of the Committee's Report in Relation to the McKenna Interview}

Four years before joining the Chamberlain-Bradbury Committee, Pigou was invited by the Secretariat of the League of Nations to submit a memorandum on credit, currency and exchange fluctuations to the 1920 International Finance Conference in Brussels (Pigou 1920). That important memorandum, which was recently discussed in some detail by Aslanbeigui and Oakes (2013), has some implications for the relationship between Pigou's and McKenna's ideas on the return to gold. These implications are discussed below.

Pigou's memorandum is forward looking to the extent that it discussed policy responses once inflation has been 'stayed' and the danger of progressive depreciation eliminated, so that a 'rough centre of equilibrium' could emerges about which exchange rates would fluctuate. Like McKenna, Pigou too was seeking stable exchange rates through stable domestic price levels. On this issue Pigou invoked the name 'purchasing power parity', which McKenna did not name in his testimony before the Committee, even though it was quite clearly the concept he has in mind.

Pigou, however, is noticeably more cautious than McKenna when reflecting on the limits of purchasing power parity. Instead of asserting that exchanges rates are 'entirely' determined by prices, Pigou points out that exchange rates may fluctuate widely around purchasing power parity mark when the normal balance of indebtedness is altered (Pigou 1920, p. 13). Similarly, exchange variability around purchasing power parity results when foreign anticipation of future price changes differs from the domestic anticipation of future price changes, which itself may be influenced by changes in the normal balance of indebtedness. But this does not reflect a disagreement between Pigou and McKenna over the relationship between exchange rates and purchasing power parity per se, but a difference in emphasis over the speed with which exchange rates adjust to changes in price levels in different circumstances.

Nevertheless, for the purpose of this paper, Pigou's memorandum makes it clear that public confidence in monetary arrangements is essential and, although it is 'theoretically attractive' to have a exchange rate that achieves parity with the price of goods rather than gold, he advocated a pragmatic return to gold in the face of distrust in the prevailing monetary regime:

\footnotetext{
"parity not with gold but with things in general is theoretically attractive. ... But it is a policy not at present understood by the business world, and it postulates a strong and resolute government commanding popular confidence. In present conditions of difficulty and distrust it is scarcely practical politics.”
}

(Pigou 1920, p. 11).

As noted earlier, McKenna too had given evidence to the Chamberlain-Bradbury Committee that public confidence in the monetary system was a significant reason for returning to the gold standard. Members of the community "understand that [gold] better than the arbitrary control of credit by the Bank of England which exits today" (McKenna in: ACP 4 F25, p. 21). It is true that in, what McKenna calls, "an intelligent world" he would join Keynes in advocating something like a permanent system in which price and exchange stability is maintained by Bank of England action on credit.

J. Bradbury: "Should you contemplate that as a permanent currency system?

McKenna: "Well, if we were living in an intelligent world, yes I should.”

(ACP 4 F25, p. 29). 
But when Bradbury asked what should apply in the world in which we are, McKenna replied: "In the world in which we are, no. ... the true argument is very in applicable in the state of ignorance in which we live." (ACP 4 F25, p. 29). Given the subject of this paper, this is a critical point. In McKenna's 'intelligent world' and Pigou's world where business understand and trust the present system, a return to the gold standard is not necessary. But neither man saw the present conditions as indicative of an 'intelligent world'. The 'state of ignorance in which we live' is such that the prevailing monetary system is 'not at present understood by the business world' and the subject of 'difficulty and mistrust', both men advocated a return to the gold standard at pre-war parity, but, as already evident in the case of McKenna, and as we shall shortly see for the case of Pigou, only after the exchange rate had returned to gold parity rate of its own accord.

The September 1924 draft Report of Chamberlain-Bradbury Committee, written by Pigou after considering the transcripts of McKenna's testimony, was drafted in three sections: I, which is untitled but deals with introductory and contextual matters; II, which is titled "The Gold Standard", and III, which is titled "The Amalgamation of the Note Issues". Given the objectives of this study, section II of Pigou's draft, on the gold standard, is of greatest relevance. Within that section, his opening paragraph mentions, and then immediately dismisses, the options of: (i) returning to the gold standard with a lesser gold content per one pound sovereign than applied under the pre-war standard (so exchange rate at parity would be achieved at a lower exchange rate than that which prevailed pre-war) and (ii) the abandonment of the gold standard altogether. Without reflection on either of these options, the following assertion is made: "as a practical present day policy for this country there is, in our opinion, no alternative comparable with the return to the former gold parity of the sovereign” (Pigou in: T160 197).

After the introductory paragraph, Pigou's section II, “The Gold Standard", is discussed under two revealing sub-headings: Is the restoration of the gold standard a matter of immediate urgency; and The three routes to the restoration of gold standard at pre-war parity. Given the purpose of this study, it is necessary to underline the coincidence between much of what Pigou wrote under these two headings and a considerable part of the testimony that McKenna presented to the Chamberlain-Bradbury Committee.

\section{Is the restoration of the gold standard a matter of immediate urgency?}

McKenna spent considerable time during his interview arguing in favour a 'wait and see' approach to the return to gold. Pigou too devoted a whole section of his draft to reflection on whether there is any urgency associated with the return to gold. His answer is that the matter won't become urgent for more than a year, to 31 December 1925, when the embargo on the export of gold would expire. That conclusion is, in Pigou's assessment, unaffected by Germany's return to the gold standard under the provisions of the Dawes Report and the desire of countries of the British Empire for Britain to return to gold. Indeed, Pigou is dismissive of the very idea that Germany's return to the gold standard could have an adverse impact on Britain because, even if the Dawes plan leads to German's successful return to parity, other countries considering associating with Germany in forming a gold standard block would refrain from doing so until experience under the new monetary regime had convinced them that Germany could permanently maintain the gold value of its currency.

\footnotetext{
"In our view, however, the provisions of the Dawes Report by no means necessarily imply that the mark will be continuously maintained at full gold parity. We do not think it inconsistent with the successful application of the recommendations of that Report that the mark would, at any rate for some considerable time, stand at a discount in relation to gold as great as that at which sterling now stands.
} 
McKenna, in his testimony, was similarly dismissive of the proposition that Germany's return to gold, by pegging the mark to the gold standard US dollar, would cause problems for sterling. In the Committee's draft of September 1924 Report, Pigou's similarly concludes that "we are not therefore convinced that this consideration need be treated as of immediate urgency” (Pigou in: T160-197, p. 5). ${ }^{15}$

As noted earlier, McKenna, pointed out in his testimony that some of Britain's selfgoverning dominions were gold producers that would, potentially, gain from a return to the gold standard. Pigou also picked up on that point by noting, in his draft of the Committee's Report, the "strong desire of the self-governing dominions" for Britain to return to the gold standard. But again, he points out that that this does not add to the urgency of reaching that position. ${ }^{16}$ His preferred approach remained that of wait and see!

\section{The three routes to the restoration of gold standard at pre-war parity}

The first of Pigou's three routes to the restoration of the gold standard is basically McKenna's preferred path, with the Bank of England adopting a banking and credit policy that maintains general price levels in Britain while waiting for the American expansion in credit to drive the dollar-pound exchange towards par before the embargo on the export of gold is removed. The second route is for the Bank of England to adopt a banking and credit policy that depresses prices in Britain to a point that the dollar-pound exchanges rates rise to par before removing the embargo on the export of gold. The third route is for the Government to announce that Britain will remove the embargo on the export of gold on a particular date in the near future, which would force the Bank of England to use banking and credit policy to return to the pre-war parity before the gold embargo is lifted. This third route is basically a variation on the scenario that led McKenna to suggest that the Chancellor, or Government in this case, would be acting like King Canute if he thinks that a simple announcement could return Britain to the god standard.

If these routes are considered with respect to the relationship between the return to parity exchange rate and British and US price levels and, which is the most basic analytical framework espoused by McKenna, these three routes may be reduced to two general paths: the non-activist non-deflationary path, whereby a neutral monetary policy is employed in Britain under the expectation that rises in US prices (route 1); and an activist deflationary path, whereby contractionary monetary policy is employed in Britain to force the rate of the return to pre-war parity (routes 2 and 3). Pigou also suggested that it is evident that the second and the third routes come to much the same thing as they involve a restriction in credit to ensure that sterling prices fall (Pigou in: T160-197, p. 7). In regard to these second path, Pigou, like McKenna, emphasises that a restriction in credit to cause sterling prices to fall must, to some degree, discourage industry and threaten employment.

\footnotetext{
${ }^{15}$ Pigou's discussion on Germany and the Dawes Plan was not retained in the final version of the Committee's report. However, it is unlikely that that it is due to dissent among the Committee members. Rather, it is probably due to the lack of urgency, noted by Pigou, together with the fact that the Dawes plan only become operational on 1 September 1924, around the time that Pigou was writing the Committee's second draft of the report, and because experience under that new arrangement, from then until submission of the final report in February 1925, had done nothing to suggest that Germany's exchange rate regime should influence the timing of Britain's return to gold.

${ }^{16}$ In Pigou's words: "We assume, however, that a definite decision as to the policy to be pursued in the near future would be communicated confidentially to the self-governing Dominions, and this might well precede by some time the adoption of an active policy on our part.” (Pigou in: T160-197, p. 5)
} 
"Plainly it [the mechanism of the process for reducing prices] is one which is undesirable if there is reasonable hope that, within a short time, American action will permit our goal being attained by the first of these three routes."

(Pigou in: T160-197, p. 7)

As there is no urgency to act for more than a year, Pigou's statement above provides more support for the wait and see approach, along the lines advanced by McKenna. This is consistent with Pigou's discussion of events in the US to determine whether there is pressure for price rises in that country that may remove the need for Britain to act on reducing price levels. That discussion is almost entirely informed by McKenna's comments on the Federal Reserve Board's policy of accumulating gold and sterilising the monetary effects of that accumulation. Pigou calls this a 'skilful policy'. He adds also that the Federal Reserve Board is seeking to stimulate trade by not sterilising all of its holds of gold and allowing 'part of their gold holdings to have its natural effect', which, as discussed earlier, is a policy that McKenna was advocating for Britain.

"In these circumstances, on the assumption that the Bank of England is willing and able to prevent sterling prices from rising in any marked degree, we conclude that the British Government should not at present take any active steps towards restoring the gold standard. ...we recommend ${ }^{17}$ that, for another year, the Government should wait upon events. If at the end of 1925 the dollar has not approximated to parity, deliberate action to secure that result may become necessary.”

(Pigou in: T160-197, pp. 8-9)

\section{The Case for the 'Pigou-McKenna School'}

Brian Reddaway has suggested that, if the September 1924 draft of the ChamberlainBradbury Committee's report had been submitted and accepted by government, disaster may have been averted.

"We have seen that, in spite of the Committee's shortcomings, we should have escaped from the tragedy if the Labour government had stayed in office for another month and accepted the Report which the Committee had virtually finished in September, 1924.”

(Reddaway, 1928, p. 28).

That draft was, of course, prepared by Pigou following careful reflection on the written record of testimony provided to the Committee by its witnesses, especially that of McKenna. The question now arises as to whether it is legitimate to speak of the 'Pigou-McKenna school' on Britain's return to gold.

The case against that proposition would place great weight on the fact that the September 1924 draft of the Report indicates that the Committee has a 'decided preference' for a permanent fixed fiduciary issue, although it was recognised in the report that this limit could not be fixed until the actual conditions of a free market for gold are known. McKenna, however, was opposed to that idea. Discretionary control of credit by the Bank of England was McKenna's instrument of choice for monetary policy, not controls on the issuing of bills, and his preference for the use of the Bank rate policy to influence credit has some similarity

\footnotetext{
${ }^{17}$ It should be noted that this recommendation is conditional on the Federal Reserve Board not reversing its policy of accommodating American price rises and prices in Britain not booming, however, Pigou also writes that: “we do not anticipate either of these contingencies.” (Pigou T160-197, p. 9).
} 
to Keynes's position. ${ }^{18}$ But that similarity should not be exaggerated as McKenna did not advocate the use of credit control as a permanent arrangement in place of the gold standard, at least not in the 'the world in which we are', which he regarded as something quite distinct from the 'intelligent world' in which it could apply. ${ }^{19}$

But in two very important ways, the similarities between Pigou's draft of the Committee's report and McKenna's testimony are so dominant and significant that they outweigh the difference noted in the previous paragraph and, in our judgement, they constitute a very strong case in favour of the legitimacy of referring to the Pigou-McKenna school. First, McKenna and Pigou both recognised that the gold standard involved policy targeted at two types of stability: exchange rate stability, achieved through credit policy direct towards maintaining domestic prices at a level that is, through relative purchasing power parity, compatible with exchange rate stability; and gold price stability, achieved through trade in gold. Related to this later point, the two men shared an appreciation for the 'skilled policy' of the Federal Reserve Board in buying gold, for gold price maintenance, and the sterilisation of the monetary impact of those surplus gold reserves. They also both recognised that Germany's return to gold, undertaken as part of the Dawes report, should have no influence on the timing of Britain's return to gold. Second, and just as importantly, the views of Pigou and McKenna on the transition to the full restauration of the old parity were cautious in equal measure. A 'wait and see' approach to the timing of Britain's return to gold was seen as desirable by both men, partly because they thought that US policies may lead to a rise in price levels in America relative to Britain and facilitate a transition back to the gold standard without having to impose contractionary monetary policy to reduce prices that would impact adversely on industry.

Interestingly, McKenna's 27 January 1925 address to the Midland Bank meeting some six months after he had been interviewed by the Chamberlain-Bradbury Committee and nearly two months before the famed dinner with Churchill, Keynes, Bradbury and Niemeyer - contains nothing that would challenge the case for the Pigou-McKenna school. In that address, McKenna remarked that restoring the gold standard was finally within grasp as the actual sterling-US dollar exchange rate had come close to its pre-war parity. As per his evidence to the Chamberlain-Bradbury Committee, he noted that that movement owed more to the recent inflation in the United States than to the previous deflationary policy at home. He also indicated that the experience of managed currency in Britain had actually kept domestic prices more stable than on the other side of the Atlantic. McKenna also recognised that a full return to gold would be more advantageous to Britain for a series of reasons, namely: the provision of a universally accepted measure of value; the automatism of the system, which minimized the risk of unwise discretion by central banks; the nation would feel better about herself for being honest to her past; the fear of driving the economy off the gold standard would act as a check to the extravagance of future governments; confidence would be restored, facilitating international trade; and conditions had improved in Europe and

\footnotetext{
18 "Whether our object is deflation or stability, the method of the Treasury and the Bank of England would be found in credit control rather than in currency control” (Keynes, ACP 4 F26, p.4).

${ }^{19}$ McKenna was also arguably more willing than Pigou to consider circumstances when the return to the gold standard should not be pursued. For example, if the cost of British contributions to the cost of gold price maintenance were too high, McKenna considered that a return to the gold standard may not be appropriate. Pigou's draft of the Committee's report was silent on this question (though perhaps this is due to caution in public documents). Furthermore, McKenna's ideal path to a resumption of the gold standard was also for events to bring the sterling to par and, once that stage had been reached, to convene an international conference to settle on the general terms for resuming the gold standard, whereas Pigou did not advocate the use of an international forum to that end (although that may be due to his responsibility to report a policy position to the Chancellor).
} 
many nations were already back to gold. Indeed, McKenna's summing up position in that address echo's Pigou's basic position:

"So long as nine people out of ten in every country think the gold standard is the best, it is the best. If in the future there were an immense increase or decrease in the output of gold and consequently a startling rise or fall in prices, re-consideration of the subject might be forced upon public attention, but at the present there is no single nation, so far as I know, which is now off the gold standard, that does not regard the return to it as the most desirable of all financial measures.”

(McKenna, 1928, p. 103).

Curiously, the strongest aspect of the case against the idea of a Pigou-McKenna school does not concern Pigou's draft of the Committee's report, but events subsequent to his drafting of that report. Pigou's reaction to critical comments from Chamberlain and Bradbury on the wait and see aspect of Pigou's September 1924 draft of the Committee's report ${ }^{20}$ demonstrated that he was not willing to defend his draft or to persuade his fellow members of the Committee to change their minds in line with what he had written.

“I am only just on balance in favour of a 'wait and see' policy. It would be inappropriate of me as an academic person to press for heroism; but if the rest of the Committee had been in favour of it, I doubt if I should have opposed.”

(Pigou in: Moggridge 1972, p. 49).

\section{Conclusion}

But in light of Reddaway's suggestion that the September 1924 draft of the Committee's report represented something of a missed opportunity in Britain's monetary history, reference to the 'Pigou-McKenna school', as a school of thought that was supportive of Britain returning to the gold standard in principle but not supportive of doing so prematurely, is an appropriate way of characterising the ideas that lay behind that missed opportunity. Furthermore, reference to the 'Pigou-McKenna school', which is also intended to characterise a missed opportunity, is arguably more meaningful than reference to the 'Keynes-McKenna school', at least to the extent that the latter incorrectly implies that McKenna was opposed to Britain returning to the gold standard.

This 'on balance' judgement in favour of the 'Pigou-McKenna school' is, we believe, given added weight when it is recalled that every quote from McKenna's testimony cited in this paper was personally highlighted by Pigou on his own copy of the Treasury's transcript of witness testimony given before the Chamberlain-Bradbury Committee.

\footnotetext{
20 "I should rather like to say definitely that (i) we are strong enough to restore the old gold parity at once and that there would be no exchange danger in announcing the very early removal of the embargo; (ii) but this would involve a sudden fall in prices which industry in its present distressed condition cannot stand; and (iii) would be improvident if, as seems likely, American prices rise, so that the sharp reduction would in large measure at least be only temporary ... To me this is the only reason for not acting now and I should like it put strongly” (Chamberlain, 11 September 1924, in: T160 197).

"For the moment we propose to wait and see which way the cat jumps. If she jumps one way, we can avoid jumping after her - and whether we can or not remains to be seen - everything will probably be all right. If it isn't, we shall be prepared to be a good deal braver than we can be at the moment. I think we ought to make it perfectly clear that we regard a return to a free gold market at the pre-war parity without long delay as of vital importance” (Bradbury, 11 September 1924, in: T160 197; and Moggridge 1972, p. 49).
} 


\section{References}

\section{Archival Documents}

ACP 4 F3, Marshall Library Archive, Papers of Arthur Cecil Pigou. 'Currency and Bank Notes Act (1914)'.

ACP 4 F22, Marshall Library Archive, Papers of Arthur Cecil Pigou. Notes taken by Treasury Reporters on the Meetings of the Committee on the Currency and Bank of England Note Issues: Testimony of Dr Walter Leaf, 4 July 1924.

ACP 4 F25, Marshall Library Archive, Papers of Arthur Cecil Pigou: Notes taken by Treasury Reporters on the Meetings of the Committee on the Currency and Bank of England Note Issues: Testimony of Mr Reginald McKenna, 10 July 1924.

ACP 4 F26, Marshall Library Archive, Papers of Arthur Cecil Pigou: Notes taken by Treasury Reporters on the Meetings of the Committee on the Currency and Bank of England Note Issues: Testimony of Mr J. M. Keynes, 11 July 1924.

G1/433, Bank of England Archive, Governor's file: Committee on the Currency and Bank of England Note Issues - Miscellaneous Papers, 21 May 1924- 28 April 1925.

T160/197, National Archives (United Kingdom); Proceedings of Chamberlain-Bradbury Committee on Gold Standard and Amalgamation of Treasury Note Issue with Bank of England Issue; evidence.

\section{Parliamentary Sources}

Currency and Bank Notes. 1914, A Bill to Authorise the Issue of Currency Notes, and to Make Provision with Respect to the Note Issue of Banks, House of Commons Parliamentary Papers, Bills, Session 1914, Vol. 361.

Currency and Bank Notes. 1925, Report of the Committee on the Currency and Bank of England Note Issues, House of Commons Parliamentary Papers, Reports of Commissioners, Session 19241925, Vol. IX.435, Paper No. Cmd 2393.

Currency and Foreign Exchanges. 1918, First Interim Report of the Committee on Currency and Foreign Exchanges after the War, House of Commons Parliamentary Papers, Reports of Commissioners, Session 1918, Paper No. Cd. 9182.

Financial Statement. 1925, Commons Sitting of Tuesday, 28th April, 1925, House of Commons Hansard, Fifth Series, Session 1924-25, Vol. 183, cc. 49-142.

Gold and Silver (Export Control, \&c.). 1920, A Bill to Control the Exportation of Gold and Silver Coin and Bullion, and to Prohibit the Melting or Improper Use of Gold and Silver Coin. House of Commons Parliamentary Papers, Bills, Session 1920, Paper No. 226.

Gold Standard. 1925, A Bill to Facilitate the Return to a Gold Standard and for Purposes Connected Therewith. House of Commons Parliamentary Papers, Bills, Session 1924-1925, Paper No. 163.

Published works

Aslanbeigui, N. and Oakes, G. 2013. 'Pigou and the Return to Gold, 1918-1925', Mini-Conference on A.C. Pigou, Robinson College, University of Cambridge, UK, 29 November 2013.

Burk, K. 1982, 'The Treasury: from Impotence to Power', in Burk, K. (Ed.), War and the State. The Transformation of the British Government, London: George Allen and Unwin, pp. 84-107.

Capie, F. and Webber, A. 1985, A Monetary History of the United Kingdom, 1870-1982. Volume 1, Data, Sources, Methods, London: George Allen and Unwin.

Crabbe, L. 1989, 'The International Gold Standard and U.S. Monetary Policy from World War I to the New Deal', Federal Reserve Bulletin, June, pp. 423-440. 
Cregier, D. M. 2004. 'Reginald McKenna (1863-1943)’, In Oxford Dictionary of National Biography, Online Edition, Oxford: Oxford University Press, Jan 2001.

Eichengreen, B. 1992, Golden Fetters: The Gold Standard and the Great Depression, 1919-1939, Oxford: Oxford University Press.

Gilbert, M. 1976, Winston S. Churchill, Volume 5, 1922-1939, London: Heinemann.

Grigg, P.J. 1948 Prejudice and Judgement, London: Jonathan Cape.

Howson, S. 2008a, 'Bradbury, John Swanwick, first Baron Bradbury (1872-1950)', Oxford Dictionary of National Biography, Oxford University Press, 2004; Online ed., Jan 2008.

Howson, S. 2008b, 'Niemeyer, Sir Otto Ernst (1883-1971)', Oxford Dictionary of National Biography, Oxford University Press, 2004; Online ed., Jan 2008.

Keynes, J. M. 1970, 'The Economic Consequences of Mr Churchill', in S. Pollard (Ed.), The Gold Standard and Employment Policies between the Wars, London: Methuen, pp. 27-43.

Keynes, J. M. 1972, 'Reginald McKenna', in D. E. Moggridge (Ed.), The Collected Writings of John Maynard Keynes, Volume X, Essays on Biography, London: Macmillan for the Royal Economic Society, pp. 58-59.

Lloyd George, David. 1938, War Memoirs of David Lloyd George, Volume 1. London: Odhams Press.

McKenna, R. 1928, Post-War Banking Policy. A Series of Addresses, London: William Heinemann.

Maier, C. S. 1988, Recasting Bourgeois Europe: Stabilization in France, Germany, and Italy in the Decade after World War I, Princeton: Princeton University Press.

Meltzer, A. H. 1983, 'Keynes on Monetary Reform and International Economic Order', The Fifth Henry Thornton Lecture, The City University, London, October 3, 1983, http://repository.cmu.edu/cgi/viewcontent.cgi?article=1795\&context=tepper

Moggridge, D. E. 1969, The Return to Gold: the formation of Economic Policy and its Critics, Cambridge: Cambridge University Press.

Moggridge, D. E. 1972, British Monetary Policy 1924-1931: The Norman Conquest of \$4.86, Cambridge: Cambridge University Press.

Morgan, V. E. 1952, Studies in British Financial Policy 1914-1925, London: Macmillan.

Mowat, R. B. 1927, A History of European Diplomacy 1914-1927, London: Edwin Arnold.

Peden, G. C. 2000, The Treasury and British Public Policy 1906-1959, Oxford: Oxford University Press.

Peters, J. 1993, 'The British Government and the City-Industry Divide: The Case of the 1914 Financial Crisis'. Twentieth Century British History, Vol. 4, No. 2, pp. 126-148.

Pigou, A. C. 1920, 'Memorandum on Credit, Currency and Exchange Fluctuations', Paper No. XIII, International Financial Conference, Brussels: The League of Nations.

Pigou, A. C. 1947. Aspects of British Economic History 1918-1925, London: Macmillan.

Reddaway, W. B. 1970, ‘Was \$4.86 Inevitable?’, Lloyds Bank Review, 96, April, pp. 15-28.

Sayers, R. S. 1970, 'The Return to Gold, 1925', in S. Pollard (Ed.). The Gold Standard and Employment Policies between the Wars, London: Methuen, pp. 85-98.

Sayers, R. S. 1976, The Bank of England, 1891-1944, Vols. 1 and 3, Cambridge: Cambridge University Press.

Seabourne, T. 1990, “The Summer of 1914”, In F. Capie and G.E. Wood (Eds.), Financial Crisis and the World Banking System, London: Macmillan, $2^{\text {nd }}$ ed., pp. 77-116. 
Skidelsky, R. 1992, 'Lost Lessons of Winston's Recession: In 1925, Keynes Warned the Chancellor of Depression”, Financial Times, Saturday, 7 November.

The Times. 1943, 'Obituary. Mr. Reginald McKenna. Statesman and Banker’, London, 7 September, Issue 49644, p. 6. 
Editor, UWA Economics Discussion Papers:

Sam Hak Kan Tang

University of Western Australia

35 Sterling Hwy

Crawley WA 6009

Australia

Email: ecoadmin@biz.uwa.edu.au

The Economics Discussion Papers are available at:

1980 - 2002: http://ecompapers.biz.uwa.edu.au/paper/PDF\%20of\%20Discussion\%20Papers/

Since 2001: http://ideas.repec.org/s/uwa/wpaper1.html

Since 2004: $\quad$ http://www.business.uwa.edu.au/school/disciplines/economics

\begin{tabular}{|c|c|c|}
\hline \multicolumn{3}{|c|}{$\begin{array}{l}\text { ECONOMICS DISCUSSION PAPERS } \\
2013\end{array}$} \\
\hline $\begin{array}{l}\text { DP } \\
\text { NUMBER }\end{array}$ & AUTHORS & TITLE \\
\hline 13.01 & $\begin{array}{l}\text { Chen, M., Clements, K.W. and } \\
\text { Gao, G. }\end{array}$ & THREE FACTS ABOUT WORLD METAL PRICES \\
\hline 13.02 & Collins, J. and Richards, O. & $\begin{array}{l}\text { EVOLUTION, FERTILITY AND THE AGEING } \\
\text { POPULATION }\end{array}$ \\
\hline 13.03 & $\begin{array}{l}\text { Clements, K., Genberg, H., } \\
\text { Harberger, A., Lothian, J., } \\
\text { Mundell, R., Sonnenschein, H. and } \\
\text { Tolley, G. }\end{array}$ & LARRY SJAASTAD, 1934-2012 \\
\hline 13.04 & Robitaille, M.C. and Chatterjee, I. & MOTHERS-IN-LAW AND SON PREFERENCE IN INDIA \\
\hline 13.05 & Clements, K.W. and Izan, I.H.Y. & $\begin{array}{l}\text { REPORT ON THE } 25^{\mathrm{TH}} \text { PHD CONFERENCE IN } \\
\text { ECONOMICS AND BUSINESS }\end{array}$ \\
\hline 13.06 & Walker, A. and Tyers, R. & QUANTIFYING AUSTRALIA’S “THREE SPEED” BOOM \\
\hline 13.07 & Yu, F. and Wu, Y. & PATENT EXAMINATION AND DISGUISED PROTECTION \\
\hline 13.08 & $\mathrm{Yu}, \mathrm{F}$. and $\mathrm{Wu}, \mathrm{Y}$. & $\begin{array}{l}\text { PATENT CITATIONS AND KNOWLEDGE SPILLOVERS: } \\
\text { AN ANALYSIS OF CHINESE PATENTS REGISTER IN } \\
\text { THE US }\end{array}$ \\
\hline 13.09 & Chatterjee, I. and Saha, B. & BARGAINING DELEGATION IN MONOPOLY \\
\hline 13.10 & Cheong, T.S. and Wu, Y. & $\begin{array}{l}\text { GLOBALIZATION AND REGIONAL INEQUALITY IN } \\
\text { CHINA }\end{array}$ \\
\hline 13.11 & Cheong, T.S. and Wu, Y. & INEQUALITY AND CRIME RATES IN CHINA \\
\hline 13.12 & Robertson, P.E. and Ye, L. & ON THE EXISTENCE OF A MIDDLE INCOME TRAP \\
\hline 13.13 & Robertson, P.E. & THE GLOBAL IMPACT OF CHINA’S GROWTH \\
\hline 13.14 & $\begin{array}{l}\text { Hanaki, N., Jacquemet, N., } \\
\text { Luchini, S., and Zylbersztejn, A. }\end{array}$ & $\begin{array}{l}\text { BOUNDED RATIONALITY AND STRATEGIC } \\
\text { UNCERTAINTY IN A SIMPLE DOMINANCE SOLVABLE } \\
\text { GAME }\end{array}$ \\
\hline 13.15 & $\begin{array}{l}\text { Okatch, Z., Siddique, A. and } \\
\text { Rammohan, A. }\end{array}$ & $\begin{array}{l}\text { DETERMINANTS OF INCOME INEQUALITY IN } \\
\text { BOTSWANA }\end{array}$ \\
\hline 13.16 & Clements, K.W. and Gao, G. & $\begin{array}{l}\text { A MULTI-MARKET APPROACH TO MEASURING THE } \\
\text { CYCLE }\end{array}$ \\
\hline
\end{tabular}




\begin{tabular}{|c|c|c|}
\hline 13.17 & Chatterjee, I. and Ray, R. & $\begin{array}{l}\text { THE ROLE OF INSTITUTIONS IN THE INCIDENCE OF } \\
\text { CRIME AND CORRUPTION }\end{array}$ \\
\hline 13.18 & Fu, D. and $\mathrm{Wu}, \mathrm{Y}$. & $\begin{array}{l}\text { EXPORT SURVIVAL PATTERN AND DETERMINANTS } \\
\text { OF CHINESE MANUFACTURING FIRMS }\end{array}$ \\
\hline 13.19 & Shi, X., Wu, Y. and Zhao, D. & $\begin{array}{l}\text { KNOWLEDGE INTENSIVE BUSINESS SERVICES AND } \\
\text { THEIR IMPACT ON INNOVATION IN CHINA }\end{array}$ \\
\hline 13.20 & $\begin{array}{l}\text { Tyers, R., Zhang, Y. and } \\
\text { Cheong, T.S. }\end{array}$ & $\begin{array}{l}\text { CHINA’S SAVING AND GLOBAL ECONOMIC } \\
\text { PERFORMANCE }\end{array}$ \\
\hline 13.21 & Collins, J., Baer, B. and Weber, E.J. & $\begin{array}{l}\text { POPULATION, TECHNOLOGICAL PROGRESS AND THE } \\
\text { EVOLUTION OF INNOVATIVE POTENTIAL }\end{array}$ \\
\hline 13.22 & Hartley, P.R. & THE FUTURE OF LONG-TERM LNG CONTRACTS \\
\hline 13.23 & Tyers, R. & $\begin{array}{l}\text { A SIMPLE MODEL TO STUDY GLOBAL } \\
\text { MACROECONOMIC INTERDEPENDENCE }\end{array}$ \\
\hline 13.24 & McLure, M. & $\begin{array}{l}\text { REFLECTIONS ON THE QUANTITY THEORY: PIGOU IN } \\
1917 \text { AND PARETO IN 1920-21 }\end{array}$ \\
\hline 13.25 & Chen, A. and Groenewold, N. & $\begin{array}{l}\text { REGIONAL EFFECTS OF AN EMISSIONS-REDUCTION } \\
\text { POLICY IN CHINA: THE IMPORTANCE OF THE } \\
\text { GOVERNMENT FINANCING METHOD }\end{array}$ \\
\hline 13.26 & Siddique, M.A.B. & $\begin{array}{l}\text { TRADE RELATIONS BETWEEN AUSTRALIA AND } \\
\text { THAILAND: } 1990 \text { TO } 2011\end{array}$ \\
\hline 13.27 & Li, B. and Zhang, J. & $\begin{array}{l}\text { GOVERNMENT DEBT IN AN INTERGENERATIONAL } \\
\text { MODEL OF ECONOMIC GROWTH, ENDOGENOUS } \\
\text { FERTILITY, AND ELASTIC LABOR WITH AN } \\
\text { APPLICATION TO JAPAN }\end{array}$ \\
\hline 13.28 & Robitaille, M. and Chatterjee, I. & $\begin{array}{l}\text { SEX-SELECTIVE ABORTIONS AND INFANT } \\
\text { MORTALITY IN INDIA: THE ROLE OF PARENTS' } \\
\text { STATED SON PREFERENCE }\end{array}$ \\
\hline 13.29 & Ezzati, P. & $\begin{array}{l}\text { ANALYSIS OF VOLATILITY SPILLOVER EFFECTS: } \\
\text { TWO-STAGE PROCEDURE BASED ON A MODIFIED } \\
\text { GARCH-M }\end{array}$ \\
\hline 13.30 & Robertson, P. E. & $\begin{array}{l}\text { DOES A FREE MARKET ECONOMY MAKE AUSTRALIA } \\
\text { MORE OR LESS SECURE IN A GLOBALISED WORLD? }\end{array}$ \\
\hline 13.31 & $\begin{array}{l}\text { Das, S., Ghate, C. and } \\
\text { Robertson, P. E. }\end{array}$ & $\begin{array}{l}\text { REMOTENESS AND UNBALANCED GROWTH: } \\
\text { UNDERSTANDING DIVERGENCE ACROSS INDIAN } \\
\text { DISTRICTS }\end{array}$ \\
\hline 13.32 & Robertson, P.E. and Sin, A. & $\begin{array}{l}\text { MEASURING HARD POWER: CHINA’S ECONOMIC } \\
\text { GROWTH AND MILITARY CAPACITY }\end{array}$ \\
\hline 13.33 & Wu, Y. & $\begin{array}{l}\text { TRENDS AND PROSPECTS FOR THE RENEWABLE } \\
\text { ENERGY SECTOR IN THE EAS REGION }\end{array}$ \\
\hline 13.34 & $\begin{array}{l}\text { Yang, S., Zhao, D., Wu, Y. and } \\
\text { Fan, J. }\end{array}$ & $\begin{array}{l}\text { REGIONAL VARIATION IN CARBON EMISSION AND } \\
\text { ITS DRIVING FORCES IN CHINA: AN INDEX } \\
\text { DECOMPOSITION ANALYSIS }\end{array}$ \\
\hline
\end{tabular}




\begin{tabular}{|c|c|c|}
\hline \multicolumn{3}{|c|}{$\begin{array}{l}\text { ECONOMICS DISCUSSION PAPERS } \\
2014\end{array}$} \\
\hline $\begin{array}{l}\text { DP } \\
\text { NUMBER }\end{array}$ & AUTHORS & TITLE \\
\hline 14.01 & $\begin{array}{l}\text { Boediono, Vice President of the Republic } \\
\text { of Indonesia }\end{array}$ & $\begin{array}{l}\text { THE CHALLENGES OF POLICY MAKING IN A } \\
\text { YOUNG DEMOCRACY: THE CASE OF INDONESIA } \\
\text { (52ND SHANN MEMORIAL LECTURE, 2013) }\end{array}$ \\
\hline 14.02 & Metaxas, P.E. and Weber, E.J. & $\begin{array}{l}\text { AN AUSTRALIAN CONTRIBUTION TO } \\
\text { INTERNATIONAL TRADE THEORY: THE } \\
\text { DEPENDENT ECONOMY MODEL }\end{array}$ \\
\hline 14.03 & Fan, J., Zhao, D., Wu, Y. and Wei, J. & $\begin{array}{l}\text { CARBON PRICING AND ELECTRICITY MARKET } \\
\text { REFORMS IN CHINA }\end{array}$ \\
\hline 14.04 & McLure, M. & $\begin{array}{l}\text { A.C. PIGOU’S MEMBERSHIP OF THE } \\
\text { 'CHAMBERLAIN-BRADBURY' COMMITTEE. } \\
\text { PART I: THE HISTORICAL CONTEXT }\end{array}$ \\
\hline 14.05 & McLure, M. & $\begin{array}{l}\text { A.C. PIGOU’S MEMBERSHIP OF THE } \\
\text { 'CHAMBERLAIN-BRADBURY’ COMMITTEE. } \\
\text { PART II: ‘TRANSITIONAL’ AND ‘ONGOING’ ISSUES }\end{array}$ \\
\hline 14.06 & King, J.E. and McLure, M. & HISTORY OF THE CONCEPT OF VALUE \\
\hline 14.07 & Williams, A. & $\begin{array}{l}\text { A GLOBAL INDEX OF INFORMATION AND } \\
\text { POLITICAL TRANSPARENCY }\end{array}$ \\
\hline 14.08 & Knight, K. & $\begin{array}{l}\text { A.C. PIGOU'S THE THEORY OF UNEMPLOYMENT } \\
\text { AND ITS CORRIGENDA: THE LETTERS OF } \\
\text { MAURICE ALLEN, ARTHUR L. BOWLEY, RICHARD } \\
\text { KAHN AND DENNIS ROBERTSON }\end{array}$ \\
\hline 14.09 & Cheong, T.S. and Wu, Y. & $\begin{array}{l}\text { THE IMPACTS OF STRUCTURAL RANSFORMATION } \\
\text { AND INDUSTRIAL UPGRADING ON REGIONAL } \\
\text { INEQUALITY IN CHINA }\end{array}$ \\
\hline 14.10 & $\begin{array}{l}\text { Chowdhury, M.H., Dewan, M.N.A., } \\
\text { Quaddus, M., Naude, M. and } \\
\text { Siddique, A. }\end{array}$ & $\begin{array}{l}\text { GENDER EQUALITY AND SUSTAINABLE } \\
\text { DEVELOPMENT WITH A FOCUS ON THE COASTAL } \\
\text { FISHING COMMUNITY OF BANGLADESH }\end{array}$ \\
\hline 14.11 & Bon, J. & $\begin{array}{l}\text { UWA DISCUSSION PAPERS IN ECONOMICS: THE } \\
\text { FIRST } 750\end{array}$ \\
\hline 14.12 & Finlay, K. and Magnusson, L.M. & $\begin{array}{l}\text { BOOTSTRAP METHODS FOR INFERENCE WITH } \\
\text { CLUSTER-SAMPLE IV MODELS }\end{array}$ \\
\hline 14.13 & Chen, A. and Groenewold, N. & $\begin{array}{l}\text { THE EFFECTS OF MACROECONOMIC SHOCKS ON } \\
\text { THE DISTRIBUTION OF PROVINCIAL OUTPUT IN } \\
\text { CHINA: ESTIMATES FROM A RESTRICTED VAR } \\
\text { MODEL }\end{array}$ \\
\hline 14.14 & Hartley, P.R. and Medlock III, K.B. & $\begin{array}{l}\text { THE VALLEY OF DEATH FOR NEW ENERGY } \\
\text { TECHNOLOGIES }\end{array}$ \\
\hline 14.15 & $\begin{array}{l}\text { Hartley, P.R., Medlock III, K.B., } \\
\text { Temzelides, T. and Zhang, X. }\end{array}$ & $\begin{array}{l}\text { LOCAL EMPLOYMENT IMPACT FROM COMPETING } \\
\text { ENERGY SOURCES: SHALE GAS VERSUS WIND } \\
\text { GENERATION IN TEXAS }\end{array}$ \\
\hline 14.16 & Tyers, R. and Zhang, Y. & $\begin{array}{l}\text { SHORT RUN EFFECTS OF THE ECONOMIC REFORM } \\
\text { AGENDA }\end{array}$ \\
\hline 14.17 & Clements, K.W., Si, J. and Simpson, T. & UNDERSTANDING NEW RESOURCE PROJECTS \\
\hline 14.18 & Tyers, R. & $\begin{array}{l}\text { SERVICE OLIGOPOLIES AND AUSTRALIA’S } \\
\text { ECONOMY-WIDE PERFORMANCE }\end{array}$ \\
\hline 14.19 & Tyers, R. and Zhang, Y. & $\begin{array}{l}\text { REAL EXCHANGE RATE DETERMINATION AND } \\
\text { THE CHINA PUZZLE }\end{array}$ \\
\hline
\end{tabular}




\begin{tabular}{|c|c|c|}
\hline \multicolumn{3}{|c|}{$\begin{array}{l}\text { ECONOMICS DISCUSSION PAPERS } \\
2014\end{array}$} \\
\hline $\begin{array}{l}\text { DP } \\
\text { NUMBER }\end{array}$ & AUTHORS & TITLE \\
\hline 14.20 & Ingram, S.R. & $\begin{array}{l}\text { COMMODITY PRICE CHANGES ARE } \\
\text { CONCENTRATED AT THE END OF THE CYCLE }\end{array}$ \\
\hline 14.21 & Cheong, T.S. and Wu, Y. & $\begin{array}{l}\text { CHINA'S INDUSTRIAL OUTPUT: A COUNTY-LEVEL } \\
\text { STUDY USING A NEW FRAMEWORK OF } \\
\text { DISTRIBUTION DYNAMICS ANALYSIS }\end{array}$ \\
\hline 14.22 & $\begin{array}{l}\text { Siddique, M.A.B., Wibowo, H. and } \\
\text { Wu, Y. }\end{array}$ & $\begin{array}{l}\text { FISCAL DECENTRALISATION AND INEQUALITY IN } \\
\text { INDONESIA: 1999-2008 }\end{array}$ \\
\hline 14.23 & Tyers, R. & $\begin{array}{l}\text { ASYMMETRY IN BOOM-BUST SHOCKS: } \\
\text { AUSTRALIAN PERFORMANCE WITH OLIGOPOLY }\end{array}$ \\
\hline 14.24 & Arora, V., Tyers, R. and Zhang, Y. & $\begin{array}{l}\text { RECONSTRUCTING THE SAVINGS GLUT: THE } \\
\text { GLOBAL IMPLICATIONS OF ASIAN EXCESS } \\
\text { SAVING }\end{array}$ \\
\hline 14.25 & Tyers, R. & $\begin{array}{l}\text { INTERNATIONAL EFFECTS OF CHINA’S RISE AND } \\
\text { TRANSITION: NEOCLASSICAL AND KEYNESIAN } \\
\text { PERSPECTIVES }\end{array}$ \\
\hline 14.26 & Milton, S. and Siddique, M.A.B. & $\begin{array}{l}\text { TRADE CREATION AND DIVERSION UNDER THE } \\
\text { THAILAND-AUSTRALIA FREE TRADE } \\
\text { AGREEMENT (TAFTA) }\end{array}$ \\
\hline 14.27 & Clements, K.W. and Li, L. & VALUING RESOURCE INVESTMENTS \\
\hline 14.28 & Tyers, R. & $\begin{array}{l}\text { PESSIMISM SHOCKS IN A MODEL OF GLOBAL } \\
\text { MACROECONOMIC INTERDEPENDENCE }\end{array}$ \\
\hline 14.29 & Iqbal, K. and Siddique, M.A.B. & $\begin{array}{l}\text { THE IMPACT OF CLIMATE CHANGE ON } \\
\text { AGRICULTURAL PRODUCTIVITY: EVIDENCE } \\
\text { FROM PANEL DATA OF BANGLADESH }\end{array}$ \\
\hline 14.30 & Ezzati, P. & $\begin{array}{l}\text { MONETARY POLICY RESPONSES TO FOREIGN } \\
\text { FINANCIAL MARKET SHOCKS: APPLICATION OF A } \\
\text { MODIFIED OPEN-ECONOMY TAYLOR RULE }\end{array}$ \\
\hline 14.31 & Tang, S.H.K. and Leung, C.K.Y. & $\begin{array}{l}\text { THE DEEP HISTORICAL ROOTS OF } \\
\text { MACROECONOMIC VOLATILITY }\end{array}$ \\
\hline 14.32 & Arthmar, R. and McLure, M. & $\begin{array}{l}\text { PIGOU, DEL VECCHIO AND SRAFFA: THE } 1955 \\
\text { INTERNATIONAL ‘ANTONIO FELTRINELLI’ PRIZE } \\
\text { FOR THE ECONOMIC AND SOCIAL SCIENCES }\end{array}$ \\
\hline 14.33 & McLure, M. & $\begin{array}{l}\text { A-HISTORIAL ECONOMIC DYNAMICS: A BOOK } \\
\text { REVIEW }\end{array}$ \\
\hline 14.34 & Clements, K.W. and Gao, G. & $\begin{array}{l}\text { THE ROTTERDAM DEMAND MODEL HALF A } \\
\text { CENTURY ON }\end{array}$ \\
\hline
\end{tabular}




\begin{tabular}{|c|c|c|}
\hline \multicolumn{3}{|c|}{$\begin{array}{l}\text { ECONOMICS DISCUSSION PAPERS } \\
2015\end{array}$} \\
\hline $\begin{array}{l}\text { DP } \\
\text { NUMBER }\end{array}$ & AUTHORS & TITLE \\
\hline 15.01 & Robertson, P.E. and Robitaille, M.C. & $\begin{array}{l}\text { THE GRAVITY OF RESOURCES AND THE TYRANNY OF } \\
\text { DISTANCE }\end{array}$ \\
\hline 15.02 & Tyers, R. & $\begin{array}{l}\text { FINANCIAL INTEGRATION AND CHINA’S GLOBAL } \\
\text { IMPACT }\end{array}$ \\
\hline 15.03 & Clements, K.W. and Si, J. & $\begin{array}{l}\text { MORE ON THE PRICE-RESPONSIVENESS OF FOOD } \\
\text { CONSUMPTION }\end{array}$ \\
\hline 15.04 & Tang, S.H.K. & $\begin{array}{l}\text { PARENTS, MIGRANT DOMESTIC WORKERS, AND } \\
\text { CHILDREN'S SPEAKING OF A SECOND LANGUAGE: } \\
\text { EVIDENCE FROM HONG KONG }\end{array}$ \\
\hline 15.05 & Tyers, R. & $\begin{array}{l}\text { CHINA AND GLOBAL MACROECONOMIC } \\
\text { INTERDEPENDENCE }\end{array}$ \\
\hline 15.06 & $\begin{array}{l}\text { Fan, J., Wu, Y., Guo, X., Zhao, D. } \\
\text { and Marinova, D. }\end{array}$ & $\begin{array}{l}\text { REGIONAL DISPARITY OF EMBEDDED CARBON } \\
\text { FOOTPRINT AND ITS SOURCES IN CHINA: A } \\
\text { CONSUMPTION PERSPECTIVE }\end{array}$ \\
\hline 15.07 & $\begin{array}{l}\text { Fan, J., Wang, S., Wu, Y., Li, J. and } \\
\text { Zhao, D. }\end{array}$ & $\begin{array}{l}\text { BUFFER EFFECT AND PRICE EFFECT OF A PERSONAL } \\
\text { CARBON TRADING SCHEME }\end{array}$ \\
\hline 15.08 & Neill, K. & $\begin{array}{l}\text { WESTERN AUSTRALIA'S DOMESTIC GAS } \\
\text { RESERVATION POLICY THE ELEMENTAL ECONOMICS }\end{array}$ \\
\hline 15.09 & Collins, J., Baer, B. and Weber, E.J. & THE EVOLUTIONARY FOUNDATIONS OF ECONOMICS \\
\hline 15.10 & $\begin{array}{l}\text { Siddique, A., Selvanathan, E. A. and } \\
\text { Selvanathan, S. }\end{array}$ & $\begin{array}{l}\text { THE IMPACT OF EXTERNAL DEBT ON ECONOMIC } \\
\text { GROWTH: EMPIRICAL EVIDENCE FROM HIGHLY } \\
\text { INDEBTED POOR COUNTRIES }\end{array}$ \\
\hline 15.11 & Wu, Y. & $\begin{array}{l}\text { LOCAL GOVERNMENT DEBT AND ECONOMIC } \\
\text { GROWTH IN CHINA }\end{array}$ \\
\hline 15.12 & Tyers, R. and Bain, I. & $\begin{array}{l}\text { THE GLOBAL ECONOMIC IMPLICATIONS OF FREER } \\
\text { SKILLED MIGRATION }\end{array}$ \\
\hline 15.13 & Chen, A. and Groenewold, N. & $\begin{array}{l}\text { AN INCREASE IN THE RETIREMENT AGE IN CHINA: } \\
\text { THE REGIONAL ECONOMIC EFFECTS }\end{array}$ \\
\hline 15.14 & Knight, K. & PIGOU, A LOYAL MARSHALLIAN? \\
\hline 15.15 & Kristoffersen, I. & $\begin{array}{l}\text { THE AGE-HAPPINESS PUZZLE: THE ROLE OF } \\
\text { ECONOMIC CIRCUMSTANCES AND FINANCIAL } \\
\text { SATISFACTION }\end{array}$ \\
\hline 15.16 & Azwar, P. and Tyers, R. & INDONESIAN MACRO POLICY THROUGH TWO CRISES \\
\hline 15.17 & Asano, A. and Tyers, R. & $\begin{array}{l}\text { THIRD ARROW REFORMS AND JAPAN'S ECONOMIC } \\
\text { PERFORMANCE }\end{array}$ \\
\hline 15.18 & Arthmar, R. and McLure, M. & $\begin{array}{l}\text { ON BRITAIN’S RETURN TO THE GOLD STANDARD: } \\
\text { WAS THERE A ‘PIGOU-MCKENNA SCHOOL’? }\end{array}$ \\
\hline 15.19 & $\begin{array}{l}\text { Fan, J., Li, Y., Wu, Y., Wang, S., } \\
\text { and Zhao, D. }\end{array}$ & $\begin{array}{l}\text { ALLOWANCE TRADING AND ENERGY CONSUMPTION } \\
\text { UNDER A PERSONAL CARBON TRADING SCHEME: A } \\
\text { DYNAMIC PROGRAMMING APPROACH }\end{array}$ \\
\hline 15.20 & Shehabi, M. & $\begin{array}{l}\text { AN EXTRAORDINARY RECOVERY: KUWAIT } \\
\text { FOLLOWING THE GULF WAR }\end{array}$ \\
\hline
\end{tabular}

